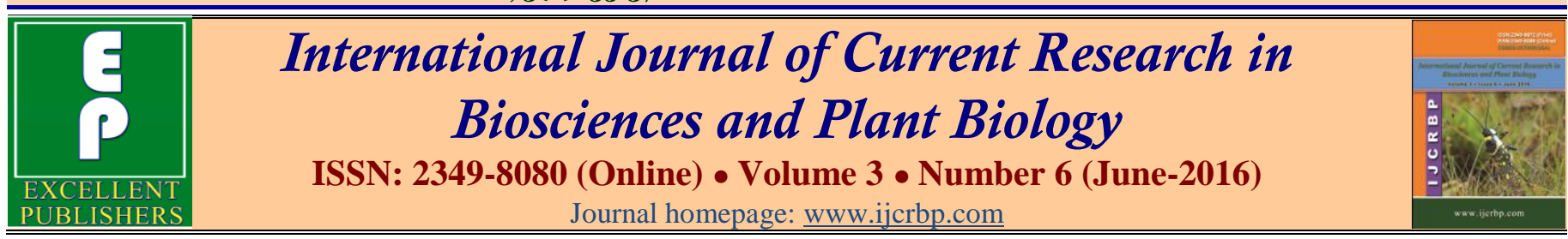

\title{
Response of Sunflower Genotypes to Sulphur Fertilization: Growth and Yield Attributes of Sunflower
}

\author{
C. Kalaiyarasan, G. Gandhi, V. Vaiyapuri, M.V. Sriramachandrasekharan, S. Jawahar* \\ and K. Sussendran
}

Department of Agronomy, Faculty of Agriculture, Annamalai University, Annamalai Nagar-608 oo2, Tamil Nadu, India

*Corresponding author.

\section{A b stract}

Field experiments were conducted at Experimental Farm, Department of Agronomy, Annamalai University, Annamalai Nagar during December 2009 and June 2010 to study the response of sunflower (Helianthus annuus L.) genotypes to sulphur levels on the growth and yield attributes. Among the different treatment combinations, KBSH 53 with $40 \mathrm{~kg} \mathrm{~S} \mathrm{ha}^{-1}$ had a spectacular effect on growth and yield attributes and yield of sunflower in I and II crops. The lowest values of growth and yield attributes were recorded by $\mathrm{CO} 4$ with $0 \mathrm{~kg} \mathrm{~S} \mathrm{ha}^{-1}$.

\section{Article Info}

Accepted: 05 May 2016

Available Online: 06 June 2016

\section{Ke y w o r d s}

Growth and yield

Helianthus annuus L.

Sulphur

Sunflower genotypes

\section{Introduction}

In India, oil seed crops constitute the second largest agricultural produce, next only to food grains and they contribute 5\% to GNP. Sunflower (Helianthus annuus L.) is the fourth important oilseed crop in India which can play an important role in reducing the shortage of edible oil and produce high yields of good quality oil for human consumption. Advantage of growing sunflower as an oilseed crop is that it can be grown throughout the year because of its photo-thermo sensitiveness character. The yield of sunflower is greatly influenced by application of fertilizers especially sulphur. Sulphur is increasingly being recognized as the fourth major plant nutrient after $\mathrm{N}, \mathrm{P}$ and $\mathrm{K}$ in view of its widespread deficiency (Sakal et al., 2001). Sulphur is considered as quality nutrient as its application not only influences crop yield but also improves crop quality owing to its influence on protein metabolism and oil synthesis. Sathish Kumar and Singh (2005) reported that application of increasing levels of $\mathrm{S}$ up to $30 \mathrm{~kg} \mathrm{ha}^{-1}$ significantly increased the yield and quality of sunflower. Hence the present study was taken up to find out the effect of $\mathrm{S}$ on the growth and yield attributes of sunflower genotypes.

\section{Materials and methods}

Field experiments were conducted during December 2009 and June 2010 at the Experimental Farm, Department of Agronomy, Annamalai University. The experimental soil was clay loam with $\mathrm{pH} 7.10$, OC $0.50 \%$, available $\mathrm{N}, \mathrm{P}, \mathrm{K}$ and $\mathrm{S}$ being $254,20.10,345$ and $17.90 \mathrm{~kg} \mathrm{ha}^{-1}$ respectively. Sunflower genotypes viz., two varieties (CO 4 and DRSF 108) and three hybrids (KBSH 53, Sunbred and Jaya) were tried along with different sulfur levels $\left(0,2,40\right.$ and $\left.60 \mathrm{~kg} \mathrm{~S} \mathrm{ha}^{-1}\right)$ through gypsum. The experiment consisted of twenty treatments and was laid out in factorial randomized block design with two replications. Recommended dose of 50:60:40 $\mathrm{kg}$ of NPK ha ${ }^{-1}$ for varieties and 60:90:60 kg of NPK ha ${ }^{-1}$ for hybrids were applied in the form of Urea, DAP and 
$\mathrm{KCl}$ respectively. Half the dose of $\mathrm{N}$ and entire dose of $\mathrm{P}$ and $\mathrm{K}$ were applied basally. The remaining quantity of $\mathrm{N}$ was applied at $30 \mathrm{DAS}$.

\section{Results and discussion}

\section{Growth attributes (Table 1)}

The genotypes influenced the growth attributes viz., plant height, LAI and DMP in both the crops. Among the different genotypes tried, KBSH 53 recorded the highest plant height at harvest $(153.79$ and $156.46 \mathrm{~cm})$, leaf area index at flowering (4.53 and 4.61), dry matter production at harvest (5152 and $5374 \mathrm{~kg} \mathrm{ha}^{-1}$ ), total chlorophyll content (2.06 and 2.15) at flowering stage and brings earliness in 50 per cent flowering (49 and 50 days) in both the crops. This was closely followed by sunbred. CO 4 recorded lowest values of plant height, LAI, DMP, total chlorophyll and takes more days to $50 \%$ flowering in both the crops. This might be due to difference of genetic makeup (Martre et al., 2009).

Among the different levels of sulphur, application of $\mathrm{S}$ at $40 \mathrm{~kg} \mathrm{ha}^{-1}$ recorded highest plant height at harvest (152 and $157 \mathrm{~cm}$ ), leaf area index at flowering (4.49 and 4.57), dry matter production at harvest (5293 and 5468 $\left.\mathrm{kg} \mathrm{ha}^{-1}\right)$, maximum total chlorophyll content at flowering stage (2.27 and 2.35) and brings earliness in days to 50\% flowering (51.2 and 50.8 days) in both the crops. The lowest values for growth attributes were recorded in the plots received $0 \mathrm{~kg} \mathrm{~S} \mathrm{ha}^{-1}$ in both the crops. The increase in growth attributes might be due to more synthesis of aminoacids, increase in chlorophyll content in growing region and improving the photosynthetic activity, ultimately enhancing cell division resulted in an increment in plant height, higher LAI and DMP. This was evidenced through the studies of Intodia and Tomer (1997) and Raja et al. (2007).

The interaction effects between the genotypes and sulphur fertilization on growth attributes were significant in both the crops. The treatment combination of $\mathrm{KBSH}$ 53 with $40 \mathrm{~kg} \mathrm{~S} \mathrm{ha}^{-1}$ recorded maximum values for growth attributes in both the crops. The higher plant growth under this combination might be due to increased utilization of carbohydrate for synthesis of protein and more availability of photosynthesis and physiological capacity to translocate them to the organ of vegetative growth (Reddy and Reddy, 2003). CO 4 with $0 \mathrm{~kg} \mathrm{~S} \mathrm{ha}^{-1}$ registered lower values for growth attributes in both the crops. This might be due to genetic nature and poor availability of S and other nutrients (Martre et al., 2009).

Table 1. Response of sunflower genotypes to sulphur fertilization on growth attributes of sunflower.

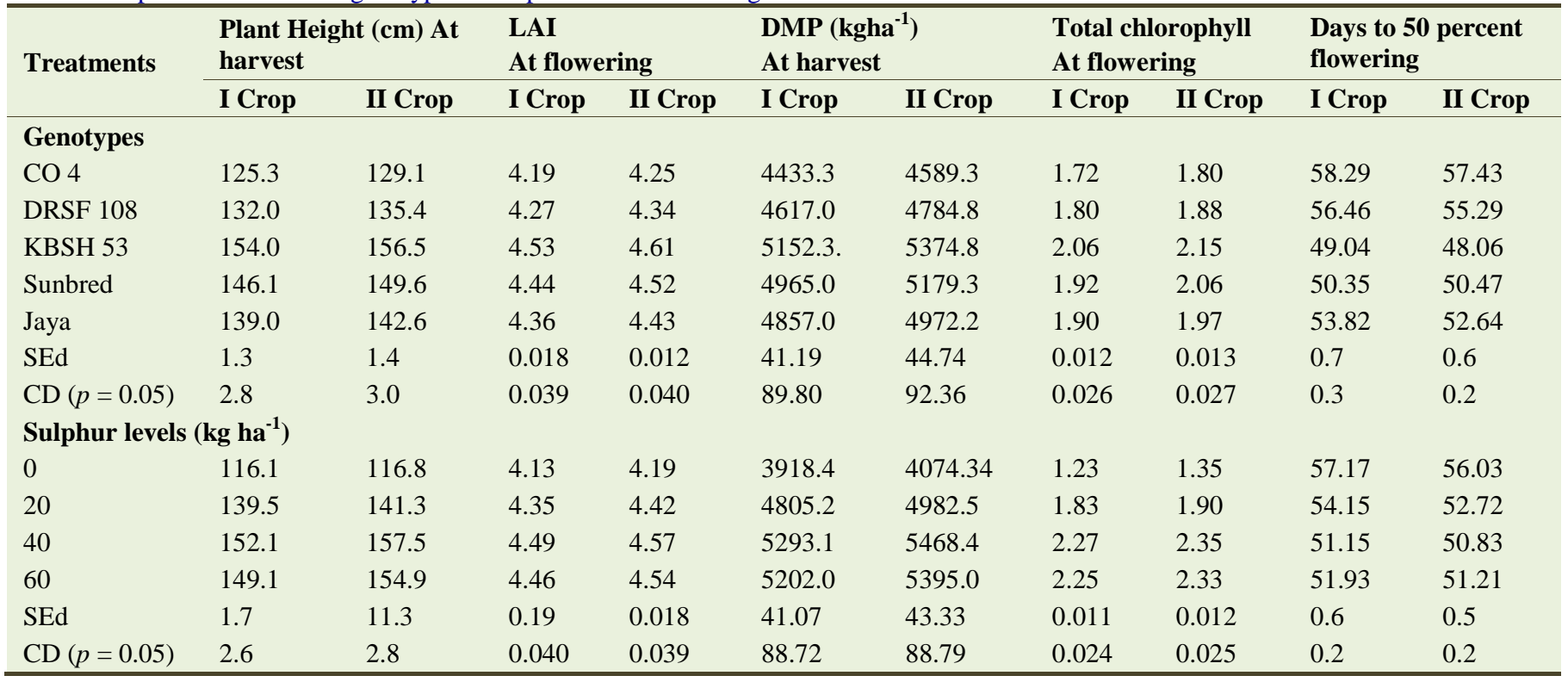

\section{Yield attributes and yield (Table 2)}

The sunflower genotypes had a significant effect on yield attributes and yield in both crops. Among the different genotypes, KBSH 53 recorded maximum head diameter
(17.5 and $19.3 \mathrm{~cm})$, total number of seeds head ${ }^{-1}(818.0$ and 854.3), 100 seed weight (5.9 and $6.11 \mathrm{~g})$ and seed yield (2145 and $2293 \mathrm{~kg} \mathrm{ha}^{-1}$ ) and stalk yield (4229 and $4446 \mathrm{~kg} \mathrm{ha}^{-1}$ ) in both the crops, respectively. This was followed by sunbred and Jaya while CO 4 recorded the 
minimum values for yield attributes and yield in both the crops. These results are in line with the findings of Yousuf et al. (1989) and Vasudevan et al. (2002).

Sulphur levels significantly influenced the yield components and yield in both the crops. Among the different levels, $\mathrm{S}$ at $40 \mathrm{~kg} \mathrm{ha}^{-1}$ produced maximum head diameter $(18.6$ and $20.4 \mathrm{~cm})$ total number of seeds head ${ }^{-1}$ (866.3 and 902.3), 100 seed weight (6.16 and $6.42 \mathrm{~g}$ ) and seed yield (2178 and $\left.2278 \mathrm{~kg} \mathrm{ha}^{-1}\right)$ and stalk yield (4422 and $4483 \mathrm{~kg} \mathrm{ha}^{-1}$ ) in both the crops. This is due to the vital role by sulphur in the formation of amino acids had a favorable effect on yield attributes due to proper portioning of photosynthetic from source to sink (Sarkar and Mallick, 2009). The least values for yield attributes were recorded under the treatment $0 \mathrm{~kg} \mathrm{~S} \mathrm{ha}{ }^{-1}$ could be due to poor availability of $S$ and other nutrients. The results are in line with the findings of Poonkodi and Poomurugesan (2005).

Table 2. Response of sunflower genotypes to sulphur fertilization on yield attributes and yield of sunflower.

\begin{tabular}{|c|c|c|c|c|c|c|c|c|c|c|}
\hline \multirow[t]{2}{*}{ Treatments } & \multicolumn{2}{|c|}{$\begin{array}{l}\text { Head diameter } \\
\text { (cm) }\end{array}$} & \multicolumn{2}{|c|}{$\begin{array}{l}\text { Total no. of seeds } \\
\text { head }^{-1}\end{array}$} & \multicolumn{2}{|c|}{$\begin{array}{l}100 \text { seed weight } \\
\text { (g) }\end{array}$} & \multicolumn{2}{|c|}{$\begin{array}{l}\text { Seed yield } \\
\left(\mathrm{kg} \mathrm{ha}^{-1}\right)\end{array}$} & \multicolumn{2}{|c|}{$\begin{array}{l}\text { Stalk yield } \\
\left(\mathrm{kg} \mathrm{ha}^{-1}\right)\end{array}$} \\
\hline & I Crop & II Crop & I Crop & II Crop & I Crop & II Crop & I Crop & II Crop & I Crop & II Crop \\
\hline \multicolumn{11}{|l|}{ Genotypes } \\
\hline $\mathrm{CO} 4$ & 15.7 & 16.7 & 670.3 & 700.5 & 5.61 & 5.80 & 1518 & 1574 & 3742 & 3791 \\
\hline DRSF 108 & 16.2 & 17.6 & 579.8 & 736.7 & 5.69 & 5.88 & 1669 & 1231 & 3898 & 3984 \\
\hline KBSH 53 & 17.5 & 19.3 & 818.0 & 854.3 & 5.90 & 6.11 & 2145 & 2293 & 4229 & 4446 \\
\hline SEd & 0.19 & 0.20 & 15.63 & 16.6 & 0.03 & 0.034 & 68.5 & 71.1 & 74.6 & 75.4 \\
\hline $\mathrm{CD}(p=0.05)$ & 0.09 & 0.09 & 7.6 & 7.9 & 0.014 & 0.016 & 34.2 & 30.9 & 37.3 & 36.8 \\
\hline \multicolumn{11}{|c|}{ Sulphur levels $\left(\mathrm{kg} \mathrm{ha}^{-1}\right)$} \\
\hline 0 & 12.6 & 13.7 & 522.8 & 557.0 & 4.95 & 5.11 & 1178 & 1275 & 3362 & 3394 \\
\hline 20 & 16.5 & 17.8 & 729.7 & 761.6 & 5.77 & 5.88 & 1809 & 1907 & 4062 & 4152 \\
\hline $\mathrm{CD}(p=0.05)$ & 0.08 & 0.09 & 7.1 & 7.1 & 0.013 & 0.014 & 33.7 & 30.4 & 36.6 & 36.8 \\
\hline
\end{tabular}

The interaction effect between genotypes and sulphur levels were found to be significant in both the crops. Among the different combinations tried, KBSH 53 along with $40 \mathrm{~kg} \mathrm{~S} \mathrm{ha}^{-1}$ registered higher values for yield components and yield in both the crops. This might be due to availability of $\mathrm{S}$ and other nutrients enhanced the yield attributing characters which finally increased the yield of the crops (Raja et al., 2007). The least values of yield attributes and yield were recorded under the treatment combination of $\mathrm{CO} 4$ with $0 \mathrm{~kg} \mathrm{~S} \mathrm{ha-1}$. This could be due to inadequate availability of $S$ and other nutrients (Govindarasu et al., 1998).

\section{Conflict of interest statement}

Authors declare that they have no conflict of interest.

\section{References}

Aguirrezabal, L., Martre, P., Pereyra-Irujo, G., Izquierdo, N., Allard, V., 2009. Management and breeding strategies for the improvement of grain and oil quality. In: Crop
Physiology. Academic Press, San Diego, CA, USA. pp.387-421.

Govindarasu, R., Sivasubramanian, P., Manian, K., 1998. Analysis of seed yield and yield components in sesame at coastal Karaikal. J. Indian Soc. Coastal Agric. Res. 7, 95-97.

Intodia, S. K., Tomar, O.P., 1997. Effect of sulphur application on growth and yield of sunflower (Helianthus annuus L). Ind. J. Agri. Sci. 67(1), 46-47.

Poonkodi, P., Poomurugesan, A.V., 2005. Efficacy of sulphur on growth and yield of sunflower (Helianthus annuus L.) Andhra Agric. J. 52(3 \& 4), 600-601.

Raja, A., Omar Hattab, K., Gurusawmy, L., Vembu, G., Suganya, K. S., 2007. Sulphur application on growth, yield and quality of sesame varieties. Int. J. Agric. Res. 2, 599-606.

Reddy, Y. R., Reddy, P.M., 2003. Yield, quality and economics of sunflower as influenced by nitrogen and sulphur nutrition. J. Oilseeds Res. 20(1), 131-132.

Sakal, R., Singh, A. P., Choudhary, B. C., Shahi, B., 2001. Sulphur status of Usifluvents and response of cops to sulphur application. Fert. News. 46(10), 61-65.

Sarkar, R. K., Mallick, R.B., 2009. Effect of nitrogen, sulphur and foliar spray of nitrate salts on performance of spring 
sunflower (Helianthus annuus L.). Ind. J. Agric. Sci. 79(12), 986-990.

Sathish Kumar, Singh, S. S., 2005. Effect of different levels of phosphorus and sulphur on the growth, yield and oil content of sunflower (Helianthus annuus L). Ind. J. Agric. Sci. 22(2), 408-409.

Vasudevan, S.N., Thimmanna, D., Shekaragouda, M., Udaikumar, M., Kurdikeri, M. B., Seetharam, A., 2002.
Influence of growth regulators on seed yield, yield parameters and oil content of sunflower genotypes. Karnataka J. Agrl. Sci. 15(1), 24-29.

Yousaf, M., Masood, A. R., Baig, A., 1989. Evaluation of sunflower cultivars under rain fed conditions. Sarahad J. Agric. 5, 73-76.

\section{How to cite this article:}

Kalaiyarasan, C., Gandhi, G., Vaiyapuri, V., Sriramachandrasekharan, M.V., Jawahar, S., Sussendran, K., 2016. Response of sunflower genotypes to sulphur fertilization: Growth and yield attributes of sunflower. Int. J. Curr. Res. Biosci. Plant Biol. 3(6), 35-37. doi: http://dx.doi.org/10.20546/ijcrbp.2016.306.005 